\title{
Type specimens of birds of the genus Batis (Aves: Platysteiridae) at the Museum für Naturkunde Berlin
}

\author{
SYLKE FRAHNERT ${ }^{1}$, MICHEL LOUETTE ${ }^{2} \&$ PASCAL ECKHOFF $^{3}$ \\ ${ }^{1}$ Museum für Naturkunde, Leibniz Institute for Evolution and Biodiversity Science, Invalidenstraße 43, D-10115 Berlin, Germany. \\ "sylke.frahnert@mfn.berlin; @ https://orcid.org/0000-0001-8486-839X \\ ${ }^{2}$ AfricaMuseum, B 3080 Tervuren, Belgium. \\ झ'michel.louette@telenet.be; 이ttps://orcid.org/0000-0001-6459-7684 \\ ${ }^{3}$ Museum für Naturkunde, Leibniz Institute for Evolution and Biodiversity Science, Invalidenstraße 43, D-10115 Berlin, Germany. \\ ”- pascal.eckhoff@mfn.berlin; — https://orcid.org/0000-0002-5995-3485
}

\begin{abstract}
The ornithological collection of the Museum für Naturkunde Berlin houses an important collection of birds of the genus Batis, with many type specimens used in descriptions dating from the 19th and beginning of the 20th century. Some of these scientific names are still in use today, but others are synonyms. We herein provide an updated list of all this type material for 10 names (species and subspecies) with 34 types and 21 paratypes, and we designate a lectotype for Batis puella Reichenow, 1893.
\end{abstract}

Key words: Aves, nomenclature, taxonomy, type, Batis

\section{Introduction}

The ZMB (Zoologisches Museum Berlin, now Museum für Naturkunde Berlin) has an important collection of birds of the genus Batis, with many type specimens used in descriptions dating from the 19th and beginning of the 20th century. Some of these scientific names are still in use today, but others are synonyms (for a critical study of the number of species and subspecies admitted by some authorities, see Louette 2006). For several names, long lists of type material with sometimes questionable determination were given (e.g. Neumann 1907a). In order to verify these, the collection of the ZMB was critically re-examined in 2019. All the specimens were re-determined. The accompanying information and historical documents were studied in detail. The localities were georeferenced. An updated list of all this type material is given here.

The genus Batis contains 19 species (del Hoyo \& Collar 2016), all of which are very similar in plumage. Sexual dimorphism in colour is pronounced in most species (males having a black breast band, females having a brownish one), but this fact was not well known to early ornithologists (see e.g. Hahn \& Küster 1850 for B. molitor Küster, 1850). All the taxa discussed in this paper belong to this group of clearly sexually dimorphic species.

A further important point for study in the museum is the fact that immature birds of both sexes resemble the female in plumage. In all species of Batis, juveniles can be separated from adults by buff tips to the wing coverts; this is evident for birds in life and in well-prepared specimens (see also Hockey et al. 2005). Determination of this is however sometimes problematic in less well-prepared specimens in transitional plumage. Because of the small size of these birds and the fact that the specimens are delicate, it is often difficult to ascertain the moult, in order to age the specimen, without damaging it.

Species of the genus Batis occur virtually everywhere in sub-Saharan Africa, but are essentially allopatric or parapatric. For instance, the closely related B. molitor and B. soror Reichenow, 1903 are parapatric in the area close to the eastern African coast (see http://tanzaniabirdatlas.net consulted on 12/09/2020). In the montane regions of southern Africa there is generally a zone of overlap along an altitudinal gradient between members of the $B$. capensis Linnaeus, 1766 superspecies (which occur primarily in forest at higher altitudes), and several other Batis species of 
more open habitat. However, altitude is not the only factor determining presence of the capensis superspecies, given that $B$. reichenowi Grote, 1911, a member of this superspecies, occurs also at low altitude (Fjeldså et al. 2006). In addition, altitude or habitat is seldom apparent from the typically rather general localities given by early collectors on their labels, and the localities given thus do not hint at the species identification of a museum specimen in these areas of ecological segregation.

For all historical localities we additionally give an actual equivalent [place, region, country, co-ordinates]. Spelling of toponyms follows Geonames (2021; geonames.org), if not otherwise mentioned. All localities are listed in Table 1. This table additionally lists the full name for all collectors if available. Nomenclature follows the International Code of Zoological Nomenclature (ICZN 1999). Current taxonomy follows del Hoyo \& Collar (2016). Museum abbreviations are as follows: AMNH = American Museum of Natural History, New York, USA; SMNS = Staatliches Museum für Naturkunde Stuttgart, Germany; ZMB = Museum für Naturkunde, Berlin, Germany. All additional information from literature, handwritten resources, etc. are given as currently interpreted in brackets [ ].

The following authors described bird species and subspecies of the Genus Batis based on ZMB specimens as new for science, with the numbers of described (sub)species given in parentheses:

Grote, Hermann (Johannes) (1882-1951): German ornithologist (1 species);

Küster, Heinrich Carl (1807-1876): German zoologist (1 species);

Lichtenstein, Martin Hinrich Carl (1780-1857): German zoologist, Director of the ZMB (1 species);

Neumann, Oscar (Rudolph) (1867-1946): German ornithologist (1 species, 4 subspecies);

Reichenow, (Georg) Anton (Eugen) (1847-1941): German ornithologist (1 species, 1 subspecies).

\section{Systematic list}

\section{Batis reichenowi Grote, 1911:162}

Now: Batis reichenowi Grote, 1911. See Louette (2006), but also Mayr et al. (1986: 379), Fjeldså et al. (2006).

Syntype: ZMB 65.130 (Grote, no. 215), skin, female, collected by H. Grote at Mikindani, 29.09.1909.

Syntype: ZMB 65.131 (Grote, no. 214), skin, male, collected by H. Grote at Mikindani, 29.09.1909.

Syntype: ZMB 65.132 (Grote, no. 179), skin, female, collected by H. Grote at Mikindani, 29.08.1909.

Type locality: Mikindani [Mikindani, Mtwara Region, Tanzania].

Remarks: In the description of Batis reichenowi Grote, 1911, no type was chosen, but both male and female were described and measurements for more than one specimen were given. Grote wrote that he collected the specimens at Mikindani. In two other publications Grote $(1912,1913)$ gave an overview of his collection from Tanzania. He listed three specimens (Grote numbers 179, 214, 215) from Mikindani as Batis reichenowi (Grote 1913: 126). Therefore, these three specimens are regarded as syntypes of Batis reichenowi.

\section{Saxicola thoracica Lichtenstein, 1823: 32}

Now: Batis capensis capensis Linnaeus, 1766. See Sharpe (1879).

Syntype: ZMB 2828, skin, former mount, male, collected by Ludwig Krebs in South Africa between 1820 and 1822.

Type locality: "Cape" = (Cape of Good Hope, South Africa), here changed to South Africa (see remarks).

Remarks: The description is part of an auction catalogue (Lichtenstein 1823). In the description no type was chosen, but Lichtenstein based the description on males only ("capitis ducta fasciaque pectoris lata atris" = head and breast with broad black band). All specimens of males offered in the auction as well as the specimens remaining in the general collection (registered mounts) and in the collection of duplicates (unregistered skins) with that species name during that time are to be considered syntypes. For all these categories the number of specimens is unknown. Furthermore, it is unknown where the specimen(s) from the auction ended up. In his printed overview about the collection Lichtenstein (1854) listed two specimens of Platystira thoracica and four of P. strepitans Lichtenstein, 1854, which was later corrected to 6 specimens of P. strepitans (handwritten correction on the printed copy in the 


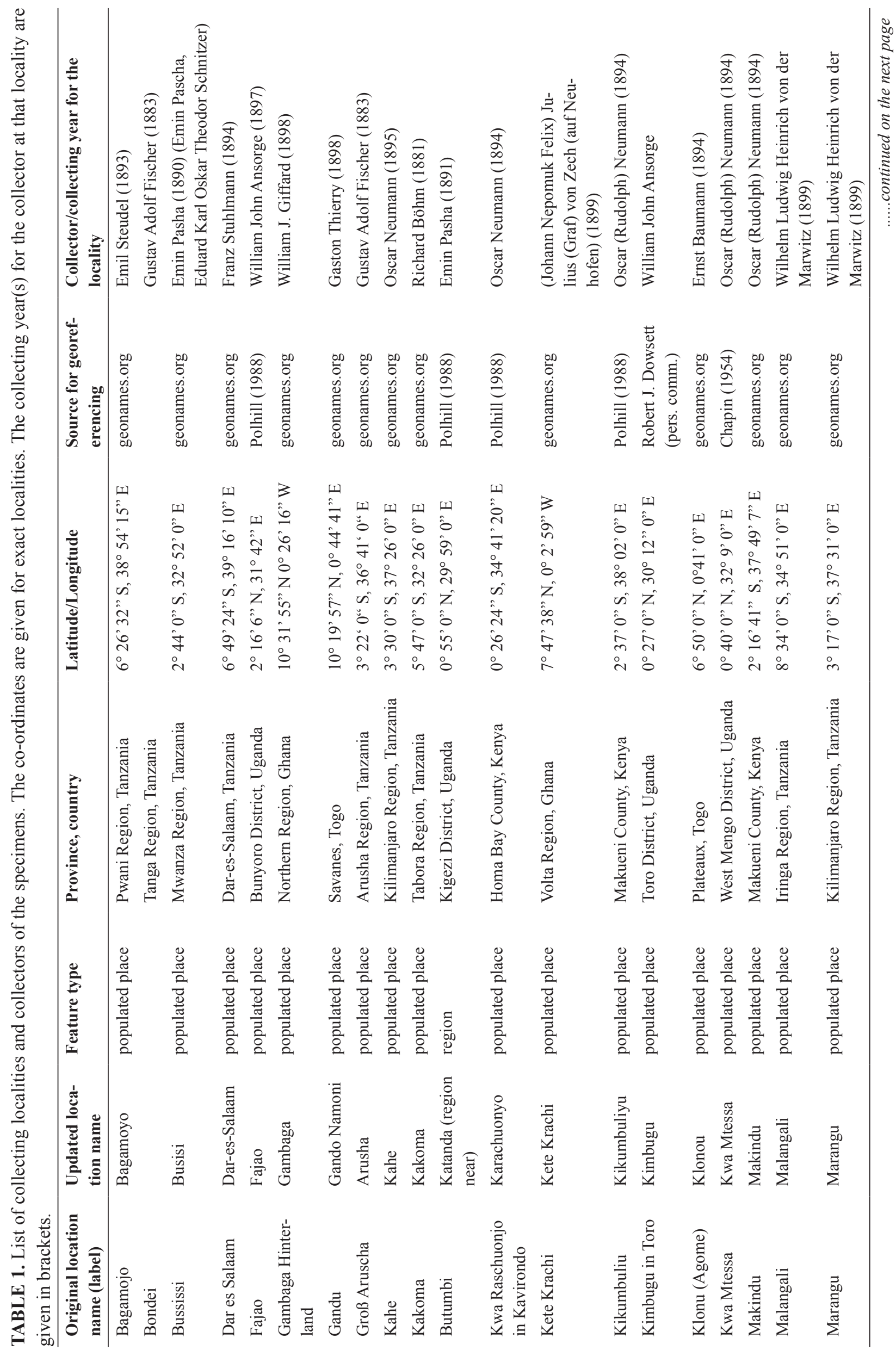




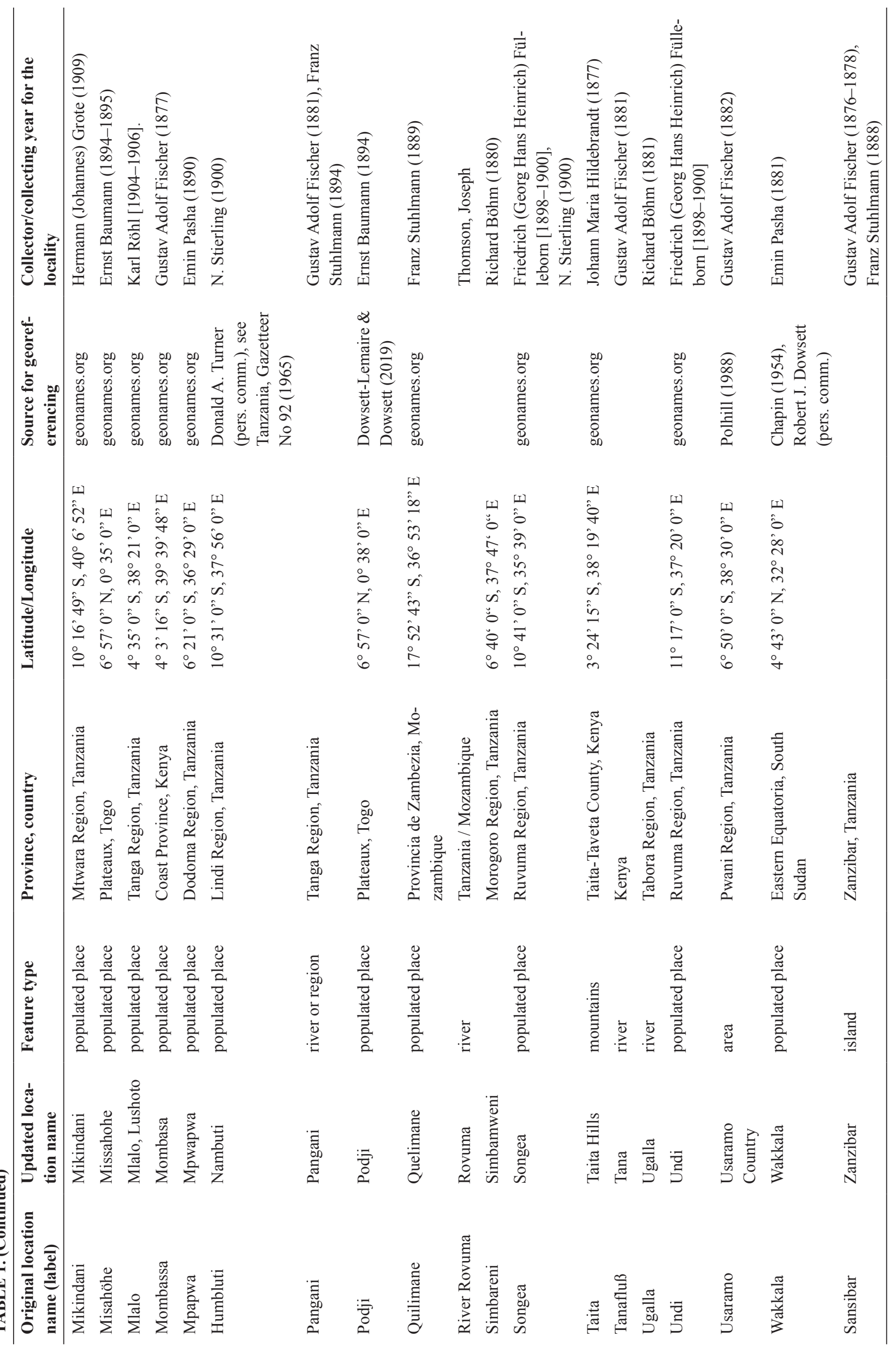


ZMB collection library). The General Collection Catalogue ZMB-AVES gives no specimens for $P$. thoracica but 6 specimens of $P$. strepitans [ZMB 2827-2829, ZMB 2831-2833, General Collection Catalogue ZMB-AVES around 1856: collected by L. Krebs (1792-1844), J. L. L. Mund (1791-1831) and L. Maire, one specimen from the collection of W. Bullock (1773-1849)], which means that the collection catalogue was produced later than Lichtenstein (1854) or independent of it. The corrections in Lichtenstein (1854) were done to bring the information of this printed work to the same standard as the collection catalogue. On the other hand, this indicates that Lichtenstein himself in fact regarded two of the six P. strepitans as P. thoracica around 1854 and that these are possible syntypes for $P$. thoracica (depending on their entry date to the museum).

As there were no inventory numbers given in the collection before 1856, the type(s) in the ZMB collection can only be identified by their historical documentation such as shipments and labels, and this was only partly possible. Four of the six specimens of $P$. strepitans/thoracica in the ZMB collection were sent by Krebs (ZMB 2828, ZMB 2831-2833). According to the shipment lists there were only three specimens of $P$. strepitans that came with Krebs' seventh shipment from "Vorgebirge der Guten Hoffnung" [South Africa] and arrived on 20 October 1823 in Berlin (Ffolliott \& Liversidge 1971). They all (two males, one female) were included in the collection and are mentioned in the entry catalogue of the museum (Lichtenstein 1811-1857; 124, 69-71). As the introduction to the auction catalogue of Lichtenstein was written in September 1823, the entry of the shipment would have been theoretically too late for inclusion in the auction catalogue. However, Lichtenstein could potentially have added a further individual later. Another possibility is that specimens arrived with earlier shipments without determinations or with an erroneous one. As an unequivocal assignment of the specimens to a single shipment is not possible, the locality cannot be ascertained. Further, the locality "Cape" as given in the description cannot be confirmed.

ZMB 2831-2833 each bear the name P. strepitans on their historical label. ZMB 2833 is a female and cannot be a type specimen. For ZMB 2828 the name Saxicola thoracica was written on a historical label during in the process of producing a study skin from the mount, a process then done especially with types (possibly around 1890). Unfortunately, the label of the mount was not kept. On the remaining label the specimen is determined as a type specimen for Saxicola thoracica. As this is the only specimen with the historical name S. thoracica in the ZMB collection, ZMB 2828 is regarded as a syntype for this species.

Specimen ZMB 2827 of the Bullock Collection arrived in Berlin in 1819 but became lost after 1856. Thus, the historical label is no longer available, and it could have been a further syntype. ZMB 2829 was sent by Mund and Maire, and arrived in Berlin in December 1823, too late to be a type specimen. On the historical label of the former mount ZMB 2829 and in the shipment list, P. strepitans is written, meaning that Lichtenstein (1854) listed this specimen as $P$. strepitans.

In summary, ZMB 2828 is the only specimen which can be assigned to the type series of Saxicola thoracica Lichtenstein, 1823. In the description, "Cape" is given as the locality. The collection catalogue gives "Südafrika" [Southern Africa] for ZMB 2828. The shipment lists for the Krebs specimens before 1823 give "Vorgebirge der Guten Hoffnung". As this is a very rough locality, and the specimens were not unquestionably assigned to the single shipments, we give South Africa as the type locality. The whereabouts of other possible type specimens from the auction are unknown.

\section{Batis puella Reichenow, 1893: 124-125}

Now: Batis molitor puella Reichenow, 1893. See Mayr et al. (1986: 381).

Lectotype (herein designated; see below for explanation): ZMB 30415 (Emin Pasha, no. 689), skin, female, collected by Emin Pasha at Bussissi, 16.10.1890.

Paralectotype: ZMB 30416 (Emin Pasha, no. 491), skin, male, collected by Emin Pasha at Bussissi, 30.09.1890.

Paralectotype: ZMB 2000.64612, skin, female, collected by J. M. Hildebrandt in Taita, 07.1877.

Paralectotype: ZMB 2000.64611 (Böhm, no. 632), skin, female, collected by R. Böhm at Kakoma, 29.08.[1881].

Paralectotype: ZMB 2000.64623 (Böhm, no. 700), mount, female, collected by R. Böhm in Ugalla, 28.10.[1881].

Paralectotype: ZMB 2000.64627 (Böhm, no. 649), skin, female, collected by R. Böhm at Kakoma, 01.09.[1881].

Paralectotype: ZMB 2000.64630 (Böhm, no. 631), skin, male, collected by R. Böhm at Kakoma, 29.08.[1881].

Paralectotype: ZMB 30279, skin, male, collected by Emin Pasha at Butumbi, 28.04.1891.

Paralectotype: ZMB 2000.64566 (Emin Pasha, no. 128), skin, male, collected by Emin Pasha at Mpapwa, 17.06.1890.

Paralectotype (missing): collected by R. Böhm at Kakoma, 07.04.[1881].

Excluded Paralectotype (B. soror): ZMB 24759 (B 15694, Fischer, no. 162), skin, former mount, female, collected by G.A. Fischer 
on Sansibar, 29.03.[18]78.

Excluded Paralectotype (B. soror): ZMB 23536 (B 15041, Fischer, no. 83), mount, female, collected by G.A. Fischer at Mombassa, 26.06.[18]77.

Excluded Paralectotype (B. soror): ZMB 28018 (Stuhlmann, no. 607), skin, male, collected by F. Stuhlmann at Quilimane, 29.01.1889.

Excluded Paralectotype (B. soror): ZMB 28019 (Stuhlmann, no. 612), skin, female, collected by F. Stuhlmann at Quilimane, 29.01.1889.

Excluded Paralectotype (B. soror): ZMB 28020 (Stuhlmann, no. 608), skin, male, collected by F. Stuhlmann at Quilimane, 29.01.1889.

Excluded Paralectotype (B. soror): ZMB 2000.6501 (Stuhlmann, no. 612), skin, female, collected by F. Stuhlmann at Quilimane, 29.01.1889.

Excluded Paralectotype (B. soror): ZMB 2000.64515 (Stuhlmann, no. 272), skin, male, collected by F. Stuhlmann on Sansibar, 03.11.1888.

Excluded Paralectotype (possibly B. pririt Vieillot, 1818, missing): Fischer, no. 631, juvenile, collected by G.A. Fischer at Bondei, 06.01.[1883].

Excluded Paralectotype (possibly B. pririt Vieillot, 1818, missing): Fischer, no. 938, male, collected by G.A. Fischer at Gross-Aruscha, 16.07.[1883].

Excluded Paralectotype (possibly B. pririt Vieillot, 1818, missing): Fischer, no. 1014, female, collected by G.A. Fischer at Pangani, 23.08.[1883].

Excluded Paralectotype (possibly B. soror, missing): collected by G.A. Fischer on the River Tana [1878].

Excluded Paralectotype (possibly B. soror, missing): collected by R. Böhm at Simbareni, 10.08.[1880].

Excluded Paralectotype (possibly B. soror, missing): collected by Thomson (?) at River Rovuma.

Type locality: Due to the lectotypification herein, the type locality of Batis puella is ascertained as Bussissi [Busisi, Mwanza Region, Tanzania].

Remarks: In the description, no single type or series of types was chosen. In principle, all listed specimens (more than 18, see Reichenow 1893) should therefore be regarded as syntypes. Seventeen of them were traced in the collection in the ZMB, Berlin (characterized by collecting data published in the description). The whereabouts of the missing specimens collected by Böhm, Fischer and Thomson are unknown. The missing specimens of Fischer of the localities Bondei, Gross-Arusha and Pangani are listes as Platystira pririt in Fischer (1884), whereas the listed locality Loeru, Ndutian is given as observation for Batis pririt in Reichenow (1887). Both specimens of F. Stuhlmann ZMB 28019 as well as 2000.6501 have the collector's number 612 on their labels, but only ZMB 2000.6501 has an original collector's label, so the collector's number of ZMB 28019 seems to be wrong. Neumann (1907a) determined that Reichenow (1893) included three different taxa in his description of puella and he assigned the species to the "form" which lives in "Ost-Afrika vom Norden des Nyassa Sees bis Uganda, im Westen bis an den Tanganyka und Kivu-See" (East Africa from north of Lake Nyassa to Uganda in the west, also to Lake Tanganyika and Lake Kivu). In a recent examination by ML, it was confirmed that the type series is indeed mixed, containing specimens belonging to B. molitor puella and to B. soror. To fix the name Batis puella on B. molitor puella, a lectotypification is necessary. The remainder of Reichenow's (1893) syntypes (those actually determined as $B . m$. puella) were taken at no less than 6 different localities. Because Vincent (1934) indicated "type from Bussisi" for B. m. puella, we formally designate ZMB 30415 (Emin Pasha, no. 689), female, as the lectotype of Batis molitor puella. This is the only female collected at the locality Busisi, and females are more diagnosable at species level than males in this taxon, as with many taxa in the genus Batis. The specimen is smaller than B. molitor molitor, according to measurements given by the collector (total length $113 \mathrm{~mm}$, wing $57.5 \mathrm{~mm}$, tail $38 \mathrm{~mm}$ ) and has a narrower chestnut breastband than in B. m. molitor. Concerning the designation of a lectotype, the type locality is ascertained to be Bussissi [Busisi, Mwanza, Tanzania]. Of all the remaining former syntypes, only those that were determined as B. m. puella are regarded as paralectotypes; the specimens determined as B. soror are excluded from the syntype series.

\section{Batis mystica Neumann, 1907b: 594}

Now: Batis molitor puella Reichenow, 1893. See Mayr et al. (1986: 381).

Holotype: ZMB 34027 skin, male, collected by O. Neumann at Kikumbuliu, 16.12.1894.

Paratype: male, collected by O. Neumann at Makindu, 15.01.1906. 
Type locality: Kikumbuliu [Kikumbuliyu, Makueni County, Kenya].

Remarks: In the description ZMB 34027 was chosen as the type specimen and is therefore the holotype. Neumann mentioned another specimen from Kenya in his collection which is therefore a paratype, but its whereabouts are unknown. The holotype is given as Pachyprora molitor puella in Neumann (1900: 256).

\section{Muscicapa molitor (Lichtenstein) Küster, 1850: 12}

Now: Batis molitor molitor (Küster, 1850). See Mayr et al. (1986: 381).

Syntype: ZMB 2838, skin, female, collected by L. Krebs in Kaffernland [South Africa].

Syntype: ZMB 2840, skin, female, collected by L. Krebs in Kaffernland [South Africa].

Type locality: "südliches Afrika" [Southern Africa], ascertained as South Africa.

Remarks: Lichtenstein used the name Batis molitor in the collection without describing the species. As Küster (in Hahn \& Küster 1850) gave the first description for this species, he is regarded as the author of that species' name. In the description no type was chosen.

Theoretically, all the specimens in the Berlin collection of 1850 which are determined as B. molitor [4, General Collection Catalogue ZMB-AVES, Lichtenstein (1854)] should be regarded as syntypes [ZMB 2837-2840, Muscicapa (Platystira) molitor]. However, Küster (1850) only described the plumage of the female and gave only the female phenotype in the figure. Therefore, only females of this species can be regarded as belonging to the type series (contra Neumann 1907a: 356). This is of special significance because in the collection catalogue and on the labels, as well as in Lichtenstein (1854), both males and females of Batis molitor were identified as belonging to that species. Thus, Küster must have seen both males and females in the collection but did not describe the very obvious sexual dimorphism of the species.

The four specimens of B. molitor in the collection from around 1850 were all collected by Ludwig Krebs. Lichtenstein associated many birds from this collector to the locality "Kaffernland" without separating the different localities given by Krebs. In the shipment lists, Muscicapa molitor is given for the ninth and tenth shipment (two males and four females, which arrived on 22.6.1825 in Berlin) and for the twelfth shipment (four males and three females, which arrived on 21.6.1830 in Berlin) (Ffolliott \& Liversidge 1971). Of these, only three specimens are listed in the entry catalogue (1811-1857) by Lichtenstein, 184/116-118 (one female, two unsexed) for 1825. No details for the shipment that arrived at the museum in 1830 are available in that catalogue. Another handwritten catalogue of 1825 (Anonymous 1825) provides the information that in 1825 four specimens of Batis molitor (two males and two females) of the ninth shipment of Krebs were mounted for the collection. Thus, it seems most probable that the four specimens (ZMB 2837-2840) in the collection belonged to that shipment. As the shipment arrived from "Vorgebirge der Guten Hoffnung" [South Africa], South Africa is regarded as the type locality. Stresemann (1954) and Ffolliott \& Liversidge (1971) gave Baviaans River 1824 as collecting data without mentioning in detail where the information came from. A printed auction catalogue of 1835 lists two specimens of Muscicapa molitor from "Kaffernland" (nos. 637 and 638, Lichtenstein 1835). Possibly the specimens that arrived in 1830 were given directly in the collection of duplicates. It was intended that they would be given away through auctions or exchange, in which case they were not mounted and so were not available for scientific work in the collection. Specimens ZMB 2834-2836 do not belong to the type series as they are males and were listed as Muscicapa (Platystira) melanoleuca Lichtenstein, 1854 in the General Collection Catalogue ZMB-AVES. ZMB 2837 and ZMB 2839 are determined as Muscicapa (Platysteira) molitor in that catalogue, but they are also males and thus cannot be types. Only ZMB 2838 and ZMB 2840 are females and are regarded as the syntypes for B. molitor. Stresemann (1954) selected ZMB 2837 as the type specimen, according to a note on the label, evidently without realising that Küster (1850) had described the female only.

\section{Batis senegalensis togoensis Neumann, 1907a: 350}

Now: Batis senegalensis (Linnaeus, 1766). See Mayr et al. (1986: 383).

Holotype: ZMB 2000.64642, skin, female, collected by E. Baumann at Misahöhe, 01.11.1894.

Paratype: ZMB 2000.64634 (Baumann, no. 92), skin, male, collected by E. Baumann at Klonu (Agome), 14.10.1894. 
Paratype: ZMB 2000.64635, skin, male, collected by G. Thierry at Gandu, 28.06.1898.

Paratype: ZMB 2000.64641, skin, female, juvenile, collected by E. Baumann at Podji, Misahöhe, 28.05.1894.

Paratype: ZMB 2000.64644 (Zech, no. 70), skin, male, juvenile, collected by (J. von Zech at Kete Krachi, 28.01.1899.

Paratype: ZMB 2000.64647, skin, male, collected by E. Baumann at Misahöhe, 01.03.1895.

Paratype: AMNH Birds SKIN-649176, male, collected by Capt. W. Giffard in the Gambaga Hinterland, Goldküste, 04.06.1898. http://portal.vertnet.org/o/amnh/birds?id=skin-649176 (16.11.2020).

Type locality: Misahöhe [Missahoe, Plateaux, Togo].

Remarks: In the description of B. senegalensis togoensis Neumann, 1907a, it is clear from collection data that ZMB 2000.64642 was chosen as the type specimen and is therefore the holotype. At least seven specimens (characterized by their collecting data) from Ghana and Togo were listed as material studied. Therefore, these specimens (excluding the holotype) should be regarded as paratypes as listed above. The specimens that were in Rothschild's private collection in Tring, UK in 1907 were transferred to the AMNH as part of Rothschild's sale of his bird collection. The type locality was ascertained for the holotype as Misahöhe [Missahoe, Plateaux, Togo] (Mayr et al. 1986).

\section{Batis puella soror Reichenow, 1903: 485}

Now: Batis soror Reichenow, 1903. See Mayr et al. (1986: 382).

Syntype: ZMB 24759 (B 15694, Fischer, no. 162), skin, former mount, female, collected by G.A. Fischer on Sansibar, 29.03.[18]78.

Syntype: ZMB 28018 (Stuhlmann, no. 607), skin, male, collected by F. Stuhlmann at Quilimane, 29.01.1889.

Syntype: ZMB 28019 (Stuhlmann, no. 612), skin, female, collected by F. Stuhlmann at Quilimane, 29.01.1889.

Syntype: ZMB 28020 (Stuhlmann, no. 608), skin, male, collected by F. Stuhlmann at Quilimane, 29.01.1889.

Syntype: ZMB 2000.6501 (Stuhlmann, no. 612), skin, female, collected by F. Stuhlmann at Quilimane, 29.01.1889.

Syntype: ZMB 2000.6502, skin, male, collected by F. Fülleborn at Undi, [1898-1900].

Syntype: ZMB 2000.64515 (Stuhlmann, no. 272), skin, male, collected by F. Stuhlmann on Sansibar, 03.11.1888.

Syntype: ZMB 2000.64541 (B 53, Stierling, no. 154), skin, male, collected by N. Stierling at Humbluti, 16.08.1900.

Syntype: ZMB 2000.64543 (B 53, Stierling, no. 83), skin, male, juvenile, collected by N. Stierling at Songea, 18.07.1900.

Syntype: ZMB 2000.64544 (B 53, Stierling, no. 143), skin, male, collected by N. Stierling at Songea, 06.08.1900.

Syntype: ZMB 2000.64545 (B 53, Stierling, no. 130), skin, female, collected by N. Stierling at Songea, 03.08.1900.

Syntype: ZMB 2000.64546, skin, male, collected by F. Fülleborn at Songea, 07. [1898-1900].

Syntype: ZMB 2000.64547 (Marwitz, no. 92), skin, female, collected by W.L.H. von der Marwitz at Malangali, 26.08. 1899.

Syntype: ZMB 2000.64563 (B 53, Stierling, no. 82), skin, male, collected by N. Stierling at Songea, 18.07.1900.

Type locality: "Sansibar und Niassagebiet bis Quilimane" [Zanzibar and the Lake (Nyassa) Malawi region to Quelimane, Tanzania, Mozambique].

Remarks: In the description of Batis puella soror Reichenow, 1903, no type was chosen. All the listed specimens are mentioned as studied material (characterized by their collecting data) in the description and are regarded as syntypes. For all types, the locality and month, but no numbers are given, so there might be further syntypes outside the ZMB. Neumann (1907a) wrongly excluded specimen ZMB 2000.64547 of the type series and corrected the locus typicus to "Songea" when he excluded the subspecies B. m. littoralis Neumann, 1907a.

\section{Batis molitor littoralis Neumann, 1907a: 356}

Now: Batis soror (Reichenow, 1903). See Mayr et al. (1986: 382).

Holotype: ZMB 24759 (B 15694, Fischer, no. 162), skin, former mount, female, collected by G.A. Fischer on Sansibar, 29.03 .76 [1878, error on the museum label as Fischer arrived in Zanzibar in 1877 for the first time].

Paratype: ZMB 23536 (B 15041, Fischer, no. 83), mount, female, collected by G.A. Fischer at Mombassa, 26.06.[18]77.

Paratype: ZMB 2000.64515 (Stuhlmann, no. 272), skin, male, collected by F. Stuhlmann on Sansibar, 03.11.1888.

Possible Paratype (missing): SMNS 10965 female, collected by E. Steudel at Bagamojo, Central Ostafrika, 1893.

Excluded Paratype (B. molitor puella): ZMB 2000.64599 (B 345, Röhl, no. 822), skin, male, collected by K. Röhl at Mlalo, [1904-1906].

Excluded Paratype (B. molitor puella): ZMB 2000.64600 (B 345, Röhl, no. 551), skin, female, collected by K. Röhl at Mlalo, [1904-1906]. 
Excluded Paratype (B. molitor puella): ZMB 2000.64602 (B 345, Röhl, no. 551), skin, male, collected by K. Röhl at Mlalo, [1904-1906].

Type locality: "Sansibar und ... die gegenüberliegende Küste” [Zanzibar and the coast of Tanzania next to Zanzibar, Tanzania], The type locality is ascertained as Zanzibar [Zanzibar, Tanzania] regarding the locality of the holotype (see Mayr et al. 1986).

Remarks: In the description ZMB 24759 was chosen as the type specimen and is therefore the holotype. The specimen is characterized by its collecting data given in the description. In summary, there were at least six specimens (characterized by their collecting data) given as studied material. Therefore, these specimens (excluding the holotype) should be regarded as paratypes. Five of them could be traced in the collection in Berlin. The specimen that Neumann had seen at the museum in Stuttgart was inventoried in the SMNS as Batis molitor but is missing today and has been since at least the 1970s (according to the museum inventory). The three specimens (ZMB 2000.64599, ZMB 2000.64600, and ZMB 2000.64602) mentioned by Neumann (1907a) as having been collected by Karl Röhl in Wilhelmsthal (Usambara) [Mlalo/Lushoto, Tanga, Tanzania] arrived as part of a shipment of more than 500 specimens in Berlin in April 1906. They have now been determined as Batis molitor puella and are thus removed from the list of possible paratypes of B. m. littoralis. Neumann (1907a) gave: "Sansibar und ... die gegenüberliegende Küste" (Zanzibar and the coast of Tanzania next to Zanzibar [Tanzania]) as type locality. The type locality of the holotype of Batis molitor littoralis Neumann, 1907a was ascertained as Zanzibar (Tanzania) (see Mayr et al. 1986).

\section{Batis minor suahelicus Neumann, 1907a: 353}

Now: Batis minor suahelica Neumann, 1907a. But see Mayr et al. (1986: 384).

Syntype: ZMB 2000.64511, skin, female, collected by G.A. Fischer at Pangani, 09.1881.

Syntype: ZMB 2000.64513, skin, male, collected by G.A. Fischer in Usaramo, 01.1882.

Syntype: ZMB 2000.64562, skin, male, collected by G.A. Fischer in Usaramo, 01.1882.

Syntype: ZMB 32010 (Stuhlmann, no. 32), skin, male, juvenile (female given by Neumann 1907a), collected by F. Stuhlmann at Pangani, 20.01.1894.

Syntype: ZMB 2000.64512 (Stuhlmann, no. 170), skin, male, collected by F. Stuhlmann at Dar-es-Salaam, 28.03.1894.

Syntype: ZMB 34024 skin, male, collected by O. Neumann at Kahe, 13.01.1895.

Syntype: ZMB 2000.64514, skin, male, collected by W.L.H. von der Marwitz at Marangu, 1895.

Syntype (missing): female, collected by R. Böhm, no locality given.

Type locality: "Deutsch Ost Afrika und südlicher Teil von Englisch Ost Afrika (Mombassa und Teita)" [Tanzania and south of Kenya], here referred to as eastern Tanzania and southeastern Kenya regarding the localities of the type specimens and the description (see also Louette 2006).

Remarks: In the description of Batis minor suahelicus Neumann, 1907a, no type was chosen. All the listed specimens are mentioned as studied material in the description, and by their collecting data are regarded as syntypes. The specimen collected by Böhm was not found in the collection. Neumann (1907a) mentioned further specimens of this species from the regions of Mombasa, Taita Hills and Malindi (including ZMB 23535, G.A. Fischer, Malindi and ZMB 2000.64673, J.M. Hildebrandt, Mombasa) which were not regarded as type specimens in the description as they are slightly smaller and seem transitional to B. minor minor. Although the description of B. m. suahelicus does not mention that a new subspecies is being described, but no other description of this subspecies is known and so Neumann (1907a) is generally accepted as the description (e.g. Mayr et al. 1986: 384). Specimen ZMB 34024 is given as Pachyprora senegalensis in Neumann (1900: 256). Sclater (1930: 422) wrongly restricted the locus typicus of Batis minor suahelicus as "Kaha, in the neighborhood of Kilimanjaro" because he interpreted ZMB 34024 as the holotype (ICZN 1999), although there is no hint that there is a holotype for this subspecies. This restriction has been taken by some authorities as a valid restriction of type locality (e.g. Mayr et al. 1986: 384).

\section{Batis minor nyansae Neumann, 1907a: 354}

Now: Batis erlangeri erlangeri Neumann, 1907a. See Mayr et al. (1986: 384).

Holotype: ZMB 34025, skin, female, collected by O. Neumann at "Kwa Mtessa in Uganda", 14.09.1894.

Paratype: ZMB 34026, skin, male, collected by O. Neumann at "Kwa Raschuonjo in Kavirondo", 06.03.1894. 
Paratype (missing or AMNH Birds SKIN-649259): male, collected by W.J. Ansorge at Kimbugu in Toro.

Paratype: AMNH Birds SKIN-649266, male, collected by W.J. Ansorge at Fadjao in Unjoro, 14.07.1897. http://portal.vertnet. org/o/amnh/birds?id=skin-649266 (10.06.2020).

Paratype: AMNH Birds SKIN-649285, female, collected by Emin Pasha (collector not given in VERTNET) at Wakkala, 25.04.[1881 (Robert J. Dowsett, pers. comm.)], http://portal.vertnet.org/o/amnh/birds?id=skin-649285 (10.06.2020).

Type locality: "Nord- und Ost-Küste des Victoria Nyansa, Albert Nyansa und oberer Weißer Nil" [north and east coast of the Lake Victoria, Lake Albert and the upper White Nile)], ascertained as "Kwa Mtessa in Uganda" [Kwa Mtessa, West Mengo District, Uganda] (see Mayr et al. 1986).

Remarks: In the description of Batis minor nyansae Neumann, 1907a, the holotype ("Typus") chosen was specimen ZMB 34025, collected by Oscar Neumann at "Kwa Mtessa in Uganda". The collecting date is given as 14.09. on the museum label. The date 14.11. in the description seems to be wrong (Pachyprora senegalensis, Neumann 1900: 256). Neumann (1907a) listed 5 further specimens in the collection in Berlin and Tring (Rothschilds private collection) as additional material he studied. All these specimens (characterized by their collecting data) are regarded as paratypes. The specimens that were in Tring in 1907 were moved to the AMNH as part of the sale of Rothschild's bird collection. AMNH Birds SKIN-649266 and AMNH Birds SKIN-649285 have the exact same collecting information as given in Neumann (1907a). However, AMNH Birds SKIN-649266 is given as male (see above), whereas in the description (Neumann, 1907a) this specimen is mentioned as female. AMNH Birds SKIN649259 (male, collected at Mahaji, (Mahagi Port), western shore of Lake Albert by Ansorge, on 16.08.1897) could not be identified with certainty as the paratype mentioned by Neumann (1907a). Neumann (1900: 256) gives a wrong inventory number for ZMB 35026 (35025). In the same publication Neumann mentions a third specimen for Pachyprora senegalensis (ZMB 35024) that was not mentioned in the type series (Neumann 1907a).

The habitat was given in the description as "Nord- und Ost-Küste des Victoria Nyansa, Albert Nyansa und oberer Weißer Nil" (northern and eastern shores of Lake Victoria, Lake Albert and the upper White Nile). It was ascertained as "Kwa Mtessa in Uganda" [Kwa Mtessa, west Mengo District, central Uganda], indicating the locality of the holotype (see Mayr et al. 1986).

\section{Additional remarks}

Lichtenstein published three further names based on specimens of the genus Batis in the Nomenclator (Lichtenstein 1854). As he gave no descriptions the names Platystira strepitans Lichtenstein, 1854, Platystira succincta Lichtenstein, 1854 and Platystira melanoleuca Lichtenstein, 1854 are nomina nuda.

The holotype and paratype of Batis minor congoensis Neumann, 1907a (now B. erlangeri congoensis), were said to be specimens collected by Friedrich Bohndorff (1848-1921) in the SMNS. Neumann (1907a) also mentioned two specimens of the collection in Berlin (ZMB 2000.64659, ZMB 31817, characterized by their collecting data) as further material he had seen, but these do not belong to the new described subspecies (Neumann (1907a) said: the form from Cameroon differs and should be named later if more material becomes available). Both specimens have now been determined as $B$. erlangeri erlangeri (see Louette 2005a). Additionally they were collected in Cameroon outside the distribution area of B. m. congoensis (see fig 2 in Louette 2005b). They do not belong to the type list, as Neumann (1907a) excluded them.

\section{Acknowledgements}

We thank Donald A. Turner (Naivasha, Kenya) for helpful discussions concerning African localities and the collection of G.A. Fischer in preparation for a special type list. Mark Adams (NHMUK, Tring) gave the crucial hint for tracking the former Tring specimens. Friederike Woog (SMNS) provided data about specimens of the SMNS and Cordula Bracker (CENAK) information about the holdings of the ZMH. Jason A. Dunlop (MfN, Berlin) improved the English. A visit to the ZMB by ML was supported by the "Taxonomiefonds" of the Museum für Naturkunde Berlin. We thank all for this support, as well as Mark Adams (NHMUK, Tring), Robert J. Dowsett (Sumene, France), Renate van den Elzen (Vienna, Austria) and Pamela C. Rasmussen (Michigan, USA) for helpful comments on the manuscript. 


\section{References}

Anonymous (1825) Verzeichnis der Ausgestopften Säugetiere und Vögel 1825. Museum für Naturkunde zu Berlin, Historische Bild- und Schriftgutsammlungen, Bestand, Zoologisches Museum, ZM S I Verwaltungsakten. s.n., s.n, 36 pp. [handwritten list, no publihsing info]

Chapin, J.P. (1954) The birds of the Belgian Congo. Part 4. Bulletin of the American Museum of Natural History, 75B, 1-846. del Hoyo, J. \& Collar, N.J. (Eds.) (2016) HBW and BirdLife International Illustrated Checklist of the Birds of the World. Vol. 2. Passerines. Lynx Edicions, Barcelona, 1012 pp.

Dowsett-Lemaire, F. \& Dowsett, R.J. (2019) The Birds of Benin and Togo, an Atlas and Handbook. Tauraco Press, Sumène, $692 \mathrm{pp}$.

Ffolliott, P. \& Liversidge, R. (1971) Ludwig Krebs, Cape Naturalist to the King of Prussia 1820-1828. A. A. Balkema, Cape Town, $304 \mathrm{pp}$.

Fischer, G.A. (1884) Übersicht der von Dr. G.A. Fischer auf seiner im Auftrag der Hamburger Geographischen Gesellschaft unternommenen Reise in das Massailand gesammelten und beobachteten Vogelarten. Zeitschrift für die gesamte Ornithologie, 1 (4), 297-396.

Fjeldså, J., Bowie, R.C.K. \& Kiure, J. (2006) The Forest Batis, Batis mixta, is two species: description of a new, narrowly distributed Batis species in the Eastern Arc biodiversity hotspot. Journal of Ornithology, 147 (4), 578-590.

GeoNames (2021) GeoNames geographical database. Available from: http://www.geonames.org/ (accessed 20 September 2021)

Grote, H. (1911) Neue Vogelarten aus Ostafrika. Ornithologische Monatsberichte, 19 (10), 162-163.

Grote, H. (1912) Beitrag zur Ornis des südöstlichen Deutsch-Ostafrika. Journal für Ornithologie, 60 (4), 501-529.

Grote, H. (1913) Beitrag zur Ornis des südöstlichen Deutsch-Ostafrika. Journal für Ornithologie, 61 (1), $125-142$.

Hahn, C.W. \& Küster, H.C. (1850) Vögel aus Asien, Afrika, Amerika und Neu-Holland, in Abbildungen nach der Natur mit Beschreibungen. Vol. 20. Lechner, Nürnberg, xx pp., 6 pls.

Hockey, P.A.R., Dean, W.R.J. \& Ryan, P.G. (Eds.) (2005) Roberts Birds of Southern Africa. John Voelcker Bird Book Fund, Cape Town, 1296 pp.

ICZN (1999) International Code of Zoological Nomenclature. $4^{\text {th }}$ Edition. International Trust for Zoological Nomenclature, London, $\mathrm{xxix}+306 \mathrm{pp}$.

Küster, H.C. (1850) Muscicapa molitor. In: Hahn, C.W. \& Küster, H.C. (1850) Vögel aus Asien, Afrika, Amerika und NeuHolland, in Abbildungen nach der Natur mit Beschreibungen. Vol. 20. Lechner, Nürnberg, xx pp., 6 pls.

Lichtenstein (1811-1857) ZMB Eingangsjournal 1811-1857, Eingangs-Journal über den Zugang an Naturalien des Königl. zoologischen Museum zu Berlin. Museum für Naturkunde zu Berlin, Historische Bild- und Schriftgutsammlungen, Bestand, Zoologisches Museum, ZM S I Eingangskatalog Zoological Museum. s.n., s.n., 391 pp. [handwritten list, no publishing info]

Lichtenstein, M.H.C. (1823) Verzeichniss der Doubletten des Zoologischen Museums der Königl. Universität zu Berlin nebst Beschreibung vieler bisher unbekannter Arten von Säugethieren, Vögeln, Amphibien und Fischen. Trautwein, Berlin, x + $118 \mathrm{pp}$.

Lichtenstein, M.H.C. (1835) Verzeichniss von Säugethieren und Vögeln, welche im Zoologischen Museum zu Berlin zu den Beigesetzten Preisen Verkauft Werden. Königliche Akademie der Wissenschaften, Berlin, 32 pp.

Lichtenstein, M.H.C. (1854) Nomenclator Avium Musei Zoologici Berolinensis. Königliche Akademie der Wissenschaften, Berlin, viii +123 pp.

Linnaeus, C. (1766) Systema Naturae. Vol. 1. 12 $2^{\text {th }}$ Revised Edition. Laurentius Salvius, Holmia, 532 pp.

Louette, M. (2005a) The Western Black-headed Batis Batis erlangeri, a separate species consisting of two subspecies. Bulletin of the African Bird Club, 12, 99-105.

Louette, M. (2005b) Conservation priorities and geographical variation in flycatchers (Aves: Platysteiridae) in the Democratic Republic ofCongo.In: Hube, B., Sinclair, B.J. \& Lampe, K.-H.(Eds.), African Biodiversity. Springer, Boston, Massachusetts, pp. 271-277.

Louette, M. (2006) Family Platysteiridae (Batises and Wattle-eyes). In: del Hoyo, J., Elliott, A. \& Christie, D.A. (Eds.), Handbook of the Birds of the World. Vol. 11. Old World Flycatchers to Old World Warblers. Lynx Editions, Barcelona, pp. 164-199.

Mayr, E., Traylor, Jr., M. A. \& Watson, G.E. (1986) Check-list of Birds of the World: a Continuation of the Work of James L. Peters. Vol. 11. Harvard University Press, Cambridge, 638 pp. https://doi.org/10.5962/bhl.title.14581

Neumann, O. (1900) Beiträge zur Vogelfauna von Ost- und Central-Afrika, part III. Journal für Ornithologie, 48 (2), $185-228$.

Neumann, O. (1907a) Revisionen afrikanischer Vogelgruppen. Journal für Ornithologie, 55 (3), 343-379.

Neumann, O. (1907b) Neue Vogel-Arten aus Nordost- und Ost-Afrika. Journal für Ornithologie, 55 (4), 593-597.

Polhill, D. (1988) Flora of Tropical East Africa. An Index of Collecting Localities. Kew Publishing, London, 398 pp.

Reichenow, A. (1887) Dr. Fischer's Ornithologische Sammlungen während der letzten Reise zum Victoria Njansa. Journal für Ornithologie, 35 (1) 38-78.

Reichenow, A. (1893) Die von Herrn Dr. Fr. Stuhlmann in Ostafrika gesammelten Vögel. Jahrbuch der Hamburgischen Wissenschaftlichen Anstalten, 10 (Jg. 1892), 109-133. 
Reichenow, A. (1903) s.n. In: Die Vögel Afrikas. Vol. 2. Part 2. Neumann, Neudamm, pp. 385-752.

Sclater, W.L. (1930) Systema Avium Aethiopicarum. Part 2. Passerines. Taylor \& Francis, London, 922 pp.

Sharpe, R.B. (1879) Catalogue of the Birds of the British Museum. Vol. 4. Taylor and Francis, London, xvi + $494 \mathrm{pp}$.

Stresemann, E. (1954) Über die von Ludwig Krebs 1820-1838 in Süd-Afrika gesammelten Vögel. Annales du Museìe du Congo belge, Zoologiques, 1, 77-82.

United States Board on Geographic Names (1965) Tanzania, Official Standard Names Approved by the United States Board on Geographic Names. Vol. 92. Defense Mapping Agency, Washington, D.C., 236 pp. [https://catalog.hathitrust.org/ Record/100122670/Cite]

Vincent, J. (1934) Review of two African species, Cyanomitra olivacea (Olive Sunbird), and Batis molitor (Chin $\square$ spot Flycatcher). Ibis, 13 (4), 85-94. 